原著

\title{
ブラッドアクセスに対する水浸法を用いた 超音波検查の有用性の検討
}

\author{
洲村 正裕*1 横木 広幸*1 別府昌子*2 本多弘*2 \\ 黒田 弘 之*3 \\ 総合病院松江生協病院泌尿器科*1 同内科*2 同放射線科*3
}

key words：ブラッドアクセス，水浸法，超音波検査，シャント血流速度

〈要旨〉

シャント血管の超音波検査，特に血流速度の正確な測定は，これまで非常に困難とされてきた。今回われわれは， シャント血管に対する水浸法を用いた超音波検査を行い，その有用性を検討した。対象は当院血液透析患者のうち， 前腕にブラッドアクセスを有する 20 例である. 超音波検査は水浸法下で，B モード，カラードプラにて血管を観察 し，パルスドプラにて血流速度の測定を行った。

シャント血管径は $6.5 \pm 1.4 \mathrm{~mm}$ ，血流速度は $689.8 \pm 326.3 \mathrm{~cm} / \mathrm{min}$ であった。

水漫法では, エコーゼリーやカプラを使って観察した場合と比較して, 血管の変形はなく, 血管内の微小な病変 まで観察することが可能であった。 また血流速度測定時には，至適な超音波入射角を維持し，血管を変形させるこ とはなく，血流波形に混入するノイズも低減できることから，シャント血管における超音波検査の問題点を十分改 善できたと思われる。

水浸法による超音波検査は, すでに報告されている超音波検査と比較して, 簡便性・正確性の両面で優れた検査 法になりうると考えられた.

\section{Evaluation of hemodialysis blood access; Doppler flowmeter and B- mode color scanner by the submersion method}

Masahiro Sumura*1, Hiroyuki Yokogi*1, Masako Beppu*2, Hiroshi Honda*2, Hiroyuki Kuroda*3 Department of Urology*1, Department of Internal Medicine*2, Department of Radiology*3, Matsue Seikyou General Hospital

It has been recognized that the accurate evaluation of hemodialysis blood access with the usual ultrasonography (US) was very difficult. To assess the efficacy of US by the submersion method in diagnosing stenosis and the blood flow rate of the blood access, US of hemodialysis blood access was performed in 20 consecutive patients with or without clinical findings of dysfunction.

The mean venous diameter was $6.5 \pm 1.4 \mathrm{~mm}$, and the mean venous blood flow rate was $689.8 \pm 326.3 \mathrm{~cm} /$ $\min$.

We observed small lesions in the hemodialysis blood access by the submersion method, because of its ability to not cause deformation of the blood vessel, compared to that by standard US methods with conductivity gel and/or acoustic coupler. In measuring the blood flow rate, the Doppler angle could be adjusted freely without any deformation of the blood vessel, and with suppression of noise in the pulse wave. So the difficulties in US assessment of blood access in hemodialysis patients is surmounted by the use of the submersion method. We conclude that US by the submersion method is superior to any previously reported US method with regard to technical ease and accuracy in assessing the hemodialysis blood access.

洲村 正裕 現 隠岐病院 T $685^{-0016}$ 島根県隠岐郡西郷町大字城北町 355

Masahiro Sumura Tel :08512-2-1356 Fax :08512-2-6149

〔受付：平成 13 年 10 月 3 日，受理：平成 14 年 2 月 22 日〕 


\section{緒言}

これまでシャント血管の超音波検査，特に血流速度 の正確な測定については困難とされ，シャント血流量

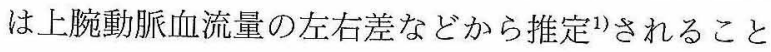
が一般的であった。直接シャント血流速度を計測した 文献 2 7)も散見されるが, 手技の難易度が高いなどのた め, さらにその検査法自体の問題点のため普及するに は至っていなかった。

今回われわれは，preliminaryではあるがシャント 血管に対する水浸法を用いた超音波検査の有用性を検 討した。

\section{II 。対象および方法}

対象は前腕に内シャントを有する血液透析患者 20 例（男性 13 例，女性 7 例）（年齢 $65.9 \pm 12.5$ 歳，透析 歴 $8.5 \pm 8.8$ 年)であった。このうち 5 例は透析時脱血 困難であった患者である，脱血困難とは，透析時に既 定の血流量が得られない場合とした，

使用装置は $10 \mathrm{MHz} \mathrm{B}$ モード, $4.5 \mathrm{MHz}$ パルスド プラ探触子を有するSA 6000 C (MEDISON CO., LTD.)を用い，水浸法で検查を行った，水浸法とは水 中に前腕とプローブの両者を置き，水を超音波媒体と して行う方法である (図 1)。今回の検討では，水温は water bag 法の $37^{\circ} \mathrm{C}$ を基準とした。 検査は $\mathrm{B}$ モードで 血管内腔を観察し，血管病変が認められた部位ではカ ラードプラで乱流の有無を検索した。血流速度はパル スドプラによりシャント血管を直接測定した。また, 従来のエコーゼリーを用いた場合（以下，従来法）あ るいは音響カプラを使用した場合（以下，カプラ法） との超音波画像の差も比較検討した。
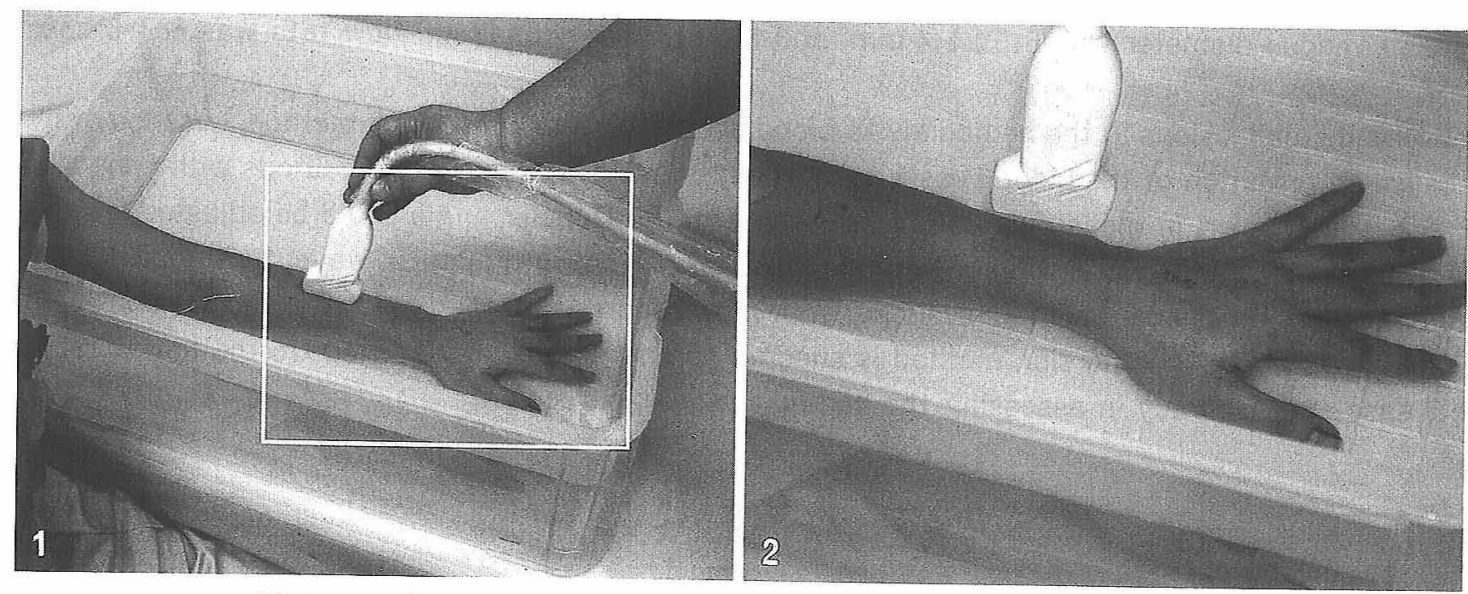

図 11 : 水浸法による超音波検查. 2 : 水浸法による超音波検査（拡大）

\section{1．血管超音波画像の差異（図 2)}

従来法では至適な焦点深度に血管近位壁が達してい ないため, 十分な観察が行えていない，焦点深度は工 コーゼリーの量で調節できる可能性 はほあるが，血管 の変形のない画像を連続的に得ることは，従来法では 非常に困難であった，カプラ法では，血管を焦点深度 内で検索することは容易であったが，従来法と同様に 血管の変形の問題を解決することは難しく，手技的な 難易度が非常に高いものであった。一方，水浸法では 血管の変形をきたすことはなく，第刺針の貫通による 血管壁の断裂部といったような内腔の微小な変化まで 容易に観察可能であった。さらに，從来法あるいはカ プラ法では超音波の隇衰が問題となる症例もみられた が，水浸法では超音波媒体が最も優れた水であり，減 衰が問題となる症例は経験しなかった。また，水浸法 では，正常前腕部皮静脈でさえも駆血等の補助的手段 を要さず連続的に描出することも可能であった（図 3)。ささに，検查方向・角度を自由に変化させること ができ, 病変部位のより詳細な検討も行い得た，

\section{2. 血流速度測定の検討}

従来法では超音波入射角の調節範囲が狭く，血管の 変形が起こり，血流が変化しやすいため正確な測定は 困難であった（図 4-1)，カプラ法では, 超音波入射角 は調節可能だが血管の変形は避けられない，水浸法で は，至適な超音波入射角を維持することができ，血流 波形へのノイズの混入を低減できるため，より正確な 測定を容易に行い得た（図 4-2)。水浸法による血流速 度測定值は，これまで報告されたもの出)同等であ り，また自験例での左右上腕動脈血流速度から算出し た値ともほほ一致をみて沶り(表)，精度的にも問題が 

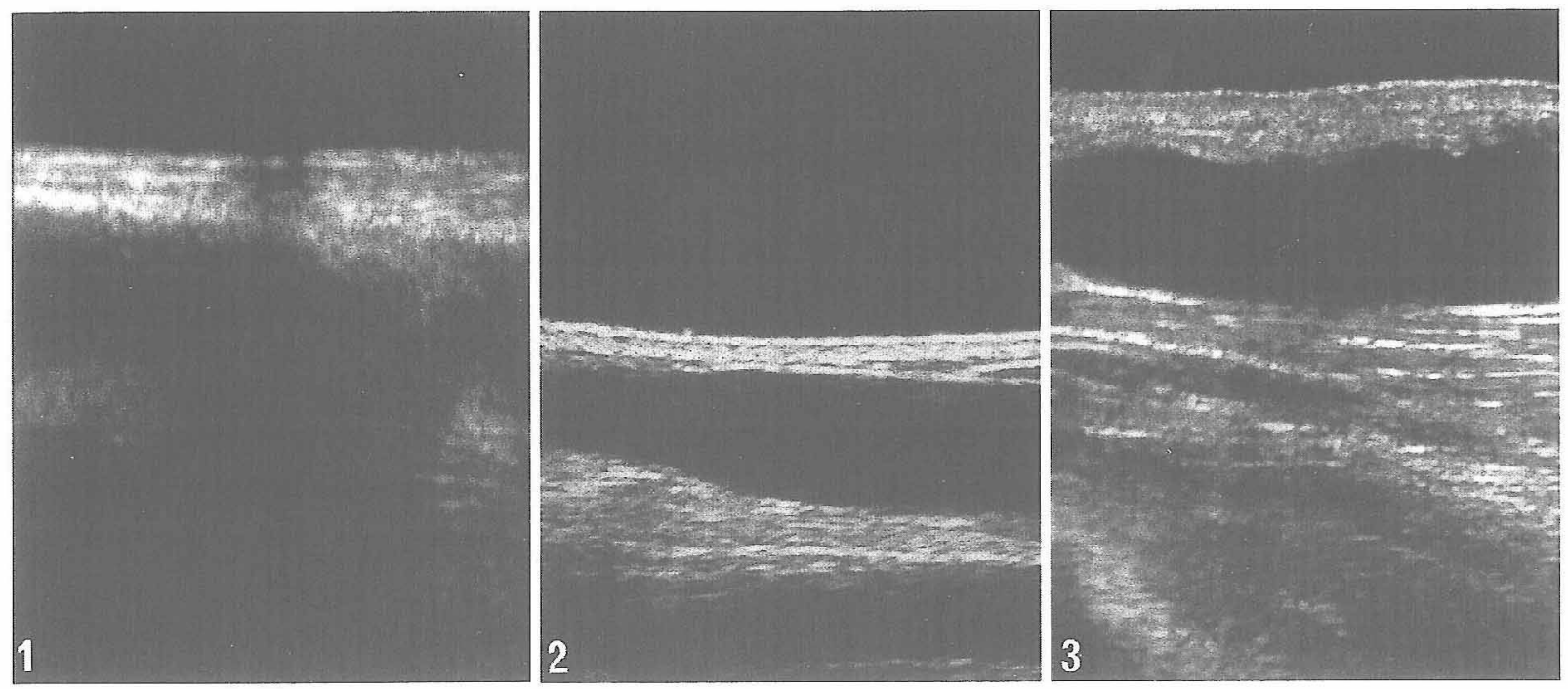

図 21 : 検査法による血管超音波検査像の差異 (従来法)。血管の変形と焦点 深度が不適切なため正確な評価は困難. 2 ：検査法による血管超音波検査 像の差異 (カプラ法)．焦点深度は適切だが血管の変形のため正確な評価 は困難． 3 : 検査法による血管超音波検査像の差異 (水浸法)。血管の圧 迫がなく至適な焦点深度での観察が可能であり, 微細な血管壁の変化ま で評価ができる。
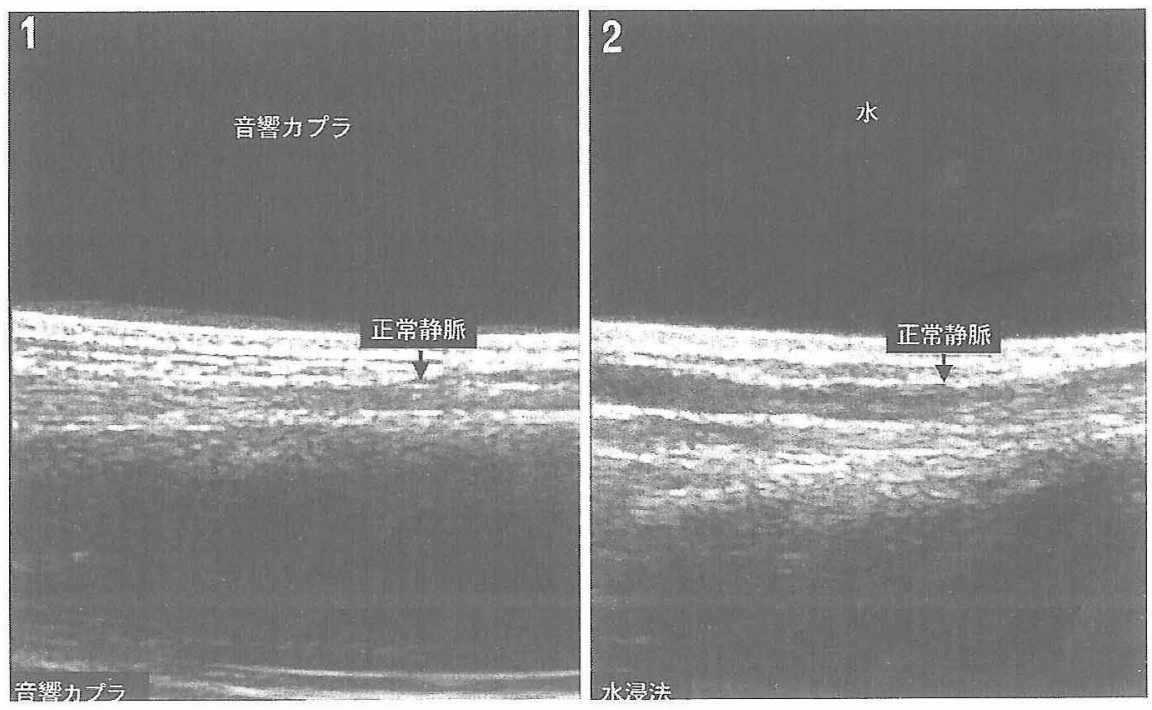

図 31 : 正常橈側皮静脈(カプラ法)。血管の変形のため連続的な描出は困難, 2 : 正常橈側皮静脈 (水浸法)。駆血等の補助手段なしに連続的に評価可能。

ないと考えられた。

\section{3. 脱血困嚾例の祫討}

透析時脱血困難がみられた 5 例で水浸法下で超音波 検査を行い，2 例に血流速度低下と血管内病変を検出 した（図 5)。この2例では，血管造影でも同部位に病 変が検出されたため，PTA を行い血流の改善をみた。 また，5例中２例では超音波検査にて血流速度低下を 認めず, 病変部位が検出されなかったため, 穿刺部位. 穿刺方向の变更あるいは穿刺施行者の変更のみで脱血 不良は改善された。また，血管造影のみで血管内病変
が診断可能であったのは 5 例中 1 例で，PTA にて血 流は改善した。

\section{III. 考 察}

内シャント血流量を把握することは患者管理に重要 であるとともに，患者自身の不安の軽減という意味で も不可欠と考えられる。従来上り，色素希釈法7)，心工 コ一図 ${ }^{8)}$ ，心放射線図 ${ }^{9)}$, thermo-dilation 法 $^{10)}$, 容積脈 波 ${ }^{11}$ を用いる方法が行われてきた。1988年阿部ら ${ }^{4)}$ 


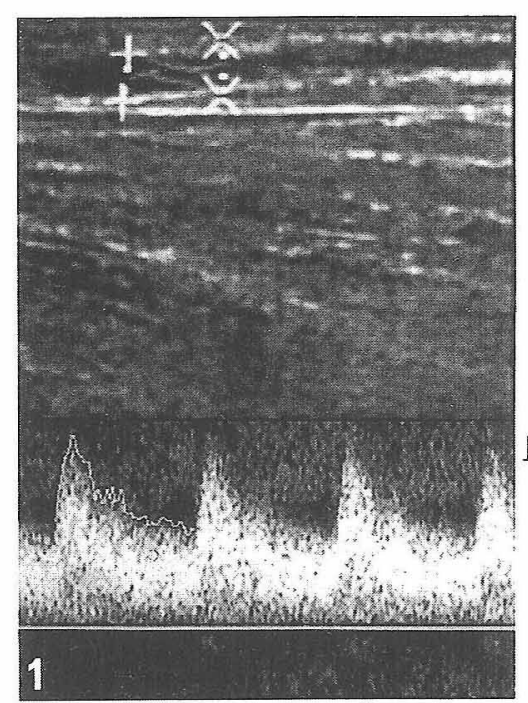

\section{超音波入射方向}
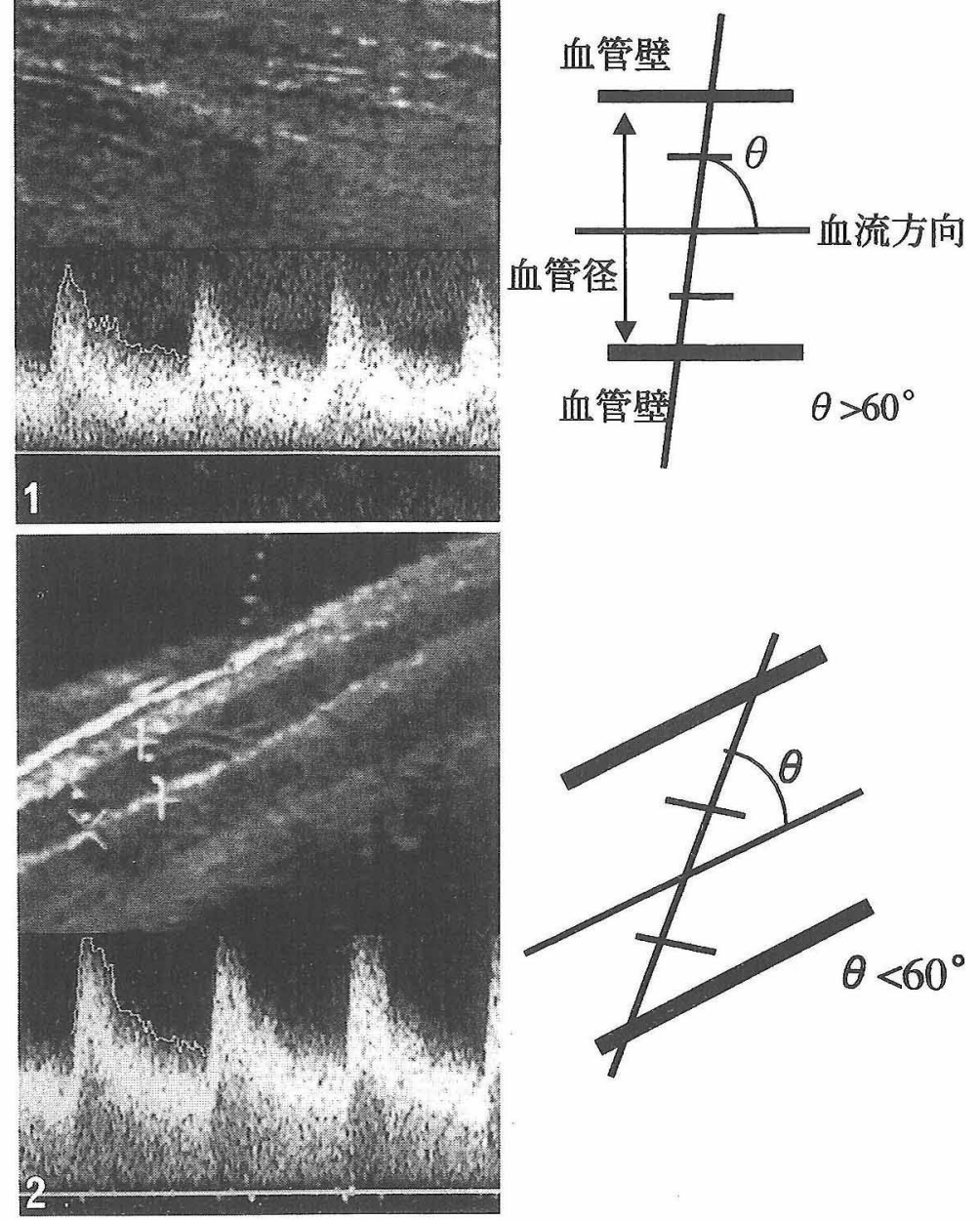

図 41 : パルス・ドプラ法による血流速度測定例(従来法). 超音波入射角度が $60^{\circ}$ 以上となり誤差が生じる。 2 : パルス・ドプラ法による血流速度測定 例 (水浸法). 超音波入射角度が自由に調節できるため正確な測定が可能.

表 上腕動脈扝よびシャント血流速度 $(\mathrm{cm} / \mathrm{sec}) \cdot$ 血流量 $(\mathrm{L} / \mathrm{min})$

\begin{tabular}{cccccccc}
\hline \multicolumn{2}{c}{ 非シャント側上腕動脈 } & & \multicolumn{2}{c}{ シャント側上腕動脈 } & & \multicolumn{2}{c}{ シャント } \\
\cline { 1 - 2 } 血流速度 & 血流量 & & 血流速度 & 血流量 & & 血流速度 & 血流量 \\
\hline $525.0 \pm 128.1$ & $0.27 \pm 0.13$ & & $832.9 \pm 184.7$ & $0.81 \pm 0.12$ & & $689.8 \pm 326.3$ & $0.64 \pm 0.32$ \\
\hline
\end{tabular}

より $\mathrm{B}$ モドパルスドプラ複合検査によるシャント 血流速度測定の報告がなされてから，超音波検査は非 侵襲的な検査法として本邦でも用いられるようになっ てきた。しかし，シャント血管の血流速度は，これま で種々の超音波検查手技で間接あるいは直接に测定さ れてきたにもかかわらず1 5)，手技が確立されておら ず，その正確性は不十分であるとされ，定着するには 至っていなかった，その問題点としては，（1)プロー ブの圧迫による変形，(2) 血流波形に混入するノイズ の多さ，(3)表在静脈であるがために超音波入射角が
不適切である, (4) 至適な焦点深度に観察刘象がない, （5）血管が蛇行して走行している，（6）血管径が不均 一であること，等がある。これらを解決するためカプ ラや water bag を用いること，エコーゼリーを厚く塗 る4ままたは超音波装置の slunt 機能で調節する゙)どの 工夫がなされてきた。 しかし、いずれの方法も課題と されてきた点を全て満足するレべルで解決できたとは 言い難く，カプラの使用やエコーゼリーを厚く塗った 場合には，超音波の減衰という新たな問題さえ生じて きた。また，血流速度测定に関しては，既存の手技で 


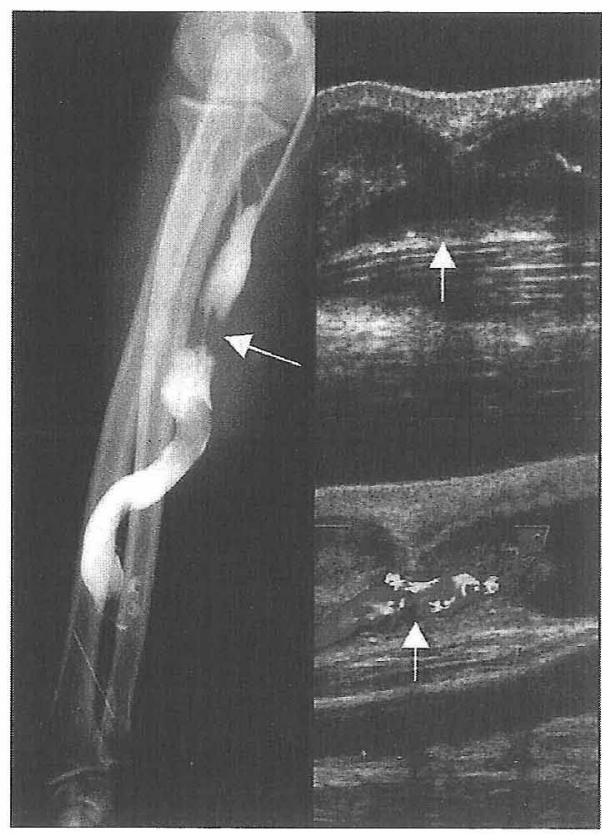

図 5 脱血困難例での血管超音波検査（水浸法）. 超音波検査結果と一致した部位に血管造影 で血栓による血管内腔の狭小化を認める。

は，シャント側と非シャント側の上腕動脈血流量の左 右差から推定したシャント血流量 ${ }^{4)}$ の精度までは到達 できていないと考えられた。つまり，動脈は通常深部 にあり，血管壁も弾性に富むので，超音波入射角を適 切にするために表皮の圧迫を行ったとしても，血管の 変形は起こりにくく, 十分正確な計測が可能であるか らである。また，動脈血流波形にはシャント血管にみ られるようなノイズの混入はなく，プローブが直接皮 膚に接触することによるデメリットが少ないという理 由もある。しかし，この手技においても，表在静脈の みでなく, 深部静脈の圧迫により測定值が実際より低 く出る可能性が残る.

われわれが用いた水浸法は，以前より放射線科領域 では一般的に用いられてきた手技であるが，われわれ の知り得る限りでは水浸法を用いてシャント血管の評 価を行った報告はなく，本検討が最初のものである， 水浸法とは検査対象である前腕およびプローブを水中 におき，水中でプローブ操作をして検査を行う方法で ある。利点としてはプローブが皮膚に接触しない，検 查方向あるいは角度を自由に調節でき，また血管との 距離を確保することが可能で測定波形に混入するノイ ズを軽減でき, 至適な焦点深度内で観察できる。さら には超音波の減衰がない，等が挙げられる，以上のよ うな利点から，これまでシャント血管の超音波検査を 困難なものとしてきた因子を排除することが可能で, より正確な検索が行えた，また，正常者の橈側皮静脈
でさえも，駆血や valsalva手技によることなく，容易 に描出でき，静脈弁の位置や狭窄の有無まで術前に検 索可能であり, 動脈血流速度測定とあわせて内シャン 卜作成前の評価に非常に有用であると思われる。さら に, これまで提案された種々の方法と比較して, 検者 に高度な熟達を要さず, 必要な器具も安価で容易に入 手できるといった利点もある。今後, 水浸法によりさ らに正確なシャント血流の管理が可能となると期待さ れる。

\section{結＼cjkstart論}

今回の検討は preliminary なものではあるが，シャ ント血管に対する水浸法を用いた超音波検査を初めて 実施し，その有用性が示されたと考える。今後, 症例 を重ね本検査法を用いた検討の信頼性の向上を図ると ともに，透析中 · 後の検査法を開発し，上腕・下肢の 検索を可能とする検查法の改良が第一の課題である。 また，検查に用いる至適な水温の検討も不可欠である と考光られた。

本論文の要旨は, 第 10 回中国腎不全研究会, 広島, 2001 年において発表した。

\section{文献}

1）吉川和暁, 北川柾彦, 菱本康之, 米山高広, 澤田善章, 鈴木唯司：超音波パルスドップラー法によるシャント 血流測定. 臨泌 53：993-998, 1999

2）久保田和義：Duplex 超音波診断装置による透析患者 内シャント血流の測定. 昭医会誌 53：138-145, 1993

3）柳沢良三, 井上重彦, 板倉宏尚, 岸 洋一：Bモード. カラードップラー複合法による血液透析用動静脈瘦の 評価. 透析会誌 $25 ： 1231-1236,1992$

4）阿部良悦：透析用ブラッドアクセスを目的とした動静 脈瘻の機能評価一超音波 $\mathrm{B}$ モード・・゚ルスドップ ラー複合法の応用一。腎と透析 $25: 203-208,1988$

5）井口 宏, 池内隆夫, 高西竜太, 松田隆夫, 吉川裕康, 浜島寿充, 佐々木春明, 甲斐祥生 : 超音波カラーフロー イメージング装置でシャント血流量を測定し内シャン 卜再建を行った 1 症例. 西日泌尿 56 ：1596-1599, 1994

6) Older RA, Gizienski TA, Wilkowski MJ, Angle JF, Cote DA : Hemodialysis access stenosis: Early detection with color doppler US. Radiology 207 : 161-164, 1998

7) Robbinson ML, Rachel F, Oser MA, Clements MW, Dockery J, Weber TM, Hamrick-Waller KM, Smith JK, Jones BC, Morgan DE, Saddekni S: Hemodialysis access graft stenosis: US detection. Radiology 208 : 655-661, 1998 
8) Johnson Jr G, Blythe WB: Hemodynamic effects of arteriovenous shunts used for hemodialysis. Ann Surg $171: 715-723,1978$

9) Von Bibra H, Castro L, Autenrieth G: The effects of arteriovenous shunts on cardiac function in renal dialysis patients. - An echocardiographic evaluation-. Clin Nephrol $9: 205-209,1978$

10）金津和朗, 永井博之, 池田正尚：血液透析用内シャン トのシャント黾と循環動態に及泟す影響について。腎
と透析 $4: 421-426,1978$

11) Dongradi G, Rocha P, Baron B: Hemodynamic effects of arterio-venous fistulae in chronic hemodialysis patients at rest and during excecise. Clin Nephrol 15:75-79, 1981

12) Hurwich BJ : Plethysmographic forearm blood flow studies in maintenance hemodialysis patients with radial arteriovenous fistulae. Nephron 6 : 673-678, 1969 